\title{
Lack of meiotic recombination in thelytokous parthenogenesis of laying workers of Apis mellifera capensis (the Cape honeybee)
}

\author{
ROBIN F. A. MORITZ* \& MICHAEL HABERL† \\ Institut für Biologie, Technische Universität Berlin, Franklinstrasse 28/29, D 10587 Berlin, Germany
}

\begin{abstract}
Offspring of thelytokous laying workers of Apis mellifera capensis were screened using multilocus DNA fingerprinting with the (GATA $)_{4}$ oligonucleotide. All screened offspring workers revealed an identical DNA fingerprint pattern, lacking evidence of any meiotic recombination. This finding supports earlier cytological studies that postulated a central fusion in the automictic thelytokous parthenogenesis of honeybees. Furthermore, crossing-over did not contribute to detectable genetic variability in this study.
\end{abstract}

Keywords: Apis mellifera capensis, automixis, DNA fingerprinting, parthenogenesis, recombination, relationship.

\section{Introduction}

In a queenright colony the queen is usually the only reproductive female. She suppresses the rearing of new queens (not in the swarming season) and the ovary development of the workers through pheromone action (Butler et al., 1961). In queenless colonies, however, this suppression is no longer effective, and the workers will either start rearing emergency queens, if appropriately aged brood is available, or develop their ovaries and become laying workers. Laying workers in honeybees usually produce unfertilized eggs that develop into male offspring. Page \& Erickson (1988) showed that such worker-produced drones can contribute substantially to the gene pool in the population. In the Cape honeybee (Apis mellifera capensis Esch.), however, laying workers are known to produce female offspring (Onions, 1912; Anderson, 1968). The fertilization mode of thelytokous parthenogenesis in honeybees was first discussed by Tucker (1958), who suggested an automixis with fusion of the two central nuclei. The location of the meiotic nuclei in queen-laid eggs differs significantly from that in worker-laid eggs in $A$. m. capensis. In queen eggs the two pairs of nuclei are arranged perpendicular to the egg surface (Snodgrass, 1925; DuPraw, 1967). Verma \& Ruttner (1983)

${ }^{*}$ Correspondence.

†Current address: Zoologisches Institut, Universität München, Louisenstrasse 14, 80333 München, Germany. observed that the four nuclei are serially arranged, parallel to the egg surface, in eggs of laying workers of the Cape honeybee. Only the two centrally located nuclei fuse to form automictically a diploid nucleus. These observations confirmed Tucker's theoretical concept of an automixis with central fusion in an empirical cytological study. The genetical consequences of the central fusion automixis are clear, giving rise to two predictions.

1 There is no random recombination of the parental chromosomes.

2 Gene recombination can occur only through crossing-over (Greeff \& Villet, 1993).

Both hypotheses can be readily tested by screening offspring of laying workers, given there are suitable genetic markers to analyse genetic recombination.

Phenotypic mutant markers which can be used to study recombination in worker offspring produced by A. m. capensis workers are potentially available in the honeybee (Tucker, 1986). The use of mutant markers for such a study is, however, laborious. Laying workers of the mutant strains perform arrhenotokous parthenogenesis and do not produce female offspring. Therefore the mutant allele has to be introduced into the $A$. $m$. capensis genome by repeated back-crossing of mutant line drones with capensis queens, and selection of the thelytokous parthenogenesis trait in laying workers. It is potentially also possible to use isozyme 
markers, but variability is low (Sylvester, 1986) and may require extensive sampling in the capensis population because only workers heterozygous at the marker locus can be used.

Molecular DNA techniques allow for simpler approaches to test the parthenogenetic mode in laying capensis workers. Multilocus DNA fingerprinting with the (GATA) ${ }_{4}$ probe (Epplen, 1988) has been shown to reveal intracolonial genetic variability among workers (Moritz et al., 1991). Haberl \& Moritz (1994) used this technique to determine the degree of polyandry in a colony of honeybees. Here we use this technique to reveal the cytogenetical mechanism which underlies the parthenogenesis of laying $A$. m. capensis workers.

\section{Materials and methods}

Single Apis mellifera capensis workers were introduced into a small nucleus colony of about 2000 queenless workers of $A$. m. carnica. The colony readily accepted the capensis worker as a pseudo-queen which started laying within 7 days. Offspring worker pupae were collected and DNA was extracted according to routine techniques (Sambrook et al., 1989). In order to determine fragment segregation in the mother colony of the laying workers, worker offspring of the queen were also collected and DNA extracted. Pupae were homogenized in $600 \mu \mathrm{L}$ ET-buffer (100 mm EDTA, $10 \mathrm{~mm}$ Tris, $\mathrm{pH} 7.5)$ and treated with $\alpha$-amylase $(250 \mu \mathrm{g}$ $\mathrm{mL}^{-1}, 10 \mathrm{~min}, 35^{\circ} \mathrm{C}$ ). SDS was added to 2 per cent final concentration in the sample, which was incubated for $15 \mathrm{~min}$ at $65^{\circ} \mathrm{C}$. Proteins and lipids were removed by one phenol/chloroform/iso-amylalcohol $(25: 24: 1)$ extraction. DNA was precipitated in isopropanol, washed twice in 70 per cent ethanol and resuspended in $100 \mu \mathrm{L}$ TE buffer $(10 \mathrm{~mm}$ Tris, $1 \mathrm{~mm}$ EDTA, $\mathrm{pH}$ 8.0). The DNA yield was approximately $5 \mu \mathrm{g}$ per pupa.

DNA fingerprinting was performed according to Epplen \& Zischler (1989) with some modifications. The DNA samples were digested with HaeIII and gel electrophoresed ( 0.7 per cent agarose) at $1.75 \mathrm{~V} \mathrm{~cm}^{-1}$ in TAE buffer $(0.04 \mathrm{~m}$ Tris acetate, $1 \mathrm{~mm}$ EDTA, $\mathrm{pH}$ $8.0)$ for $12 \mathrm{~h}$. The gels were denaturated $(0.5 \mathrm{M} \mathrm{NaOH}$, $1.5 \mathrm{M} \mathrm{NaCl}, 2 \times 15 \mathrm{~min})$, neutralized $(0.5 \mathrm{M}$ Tris; $1.5 \mathrm{M}$ $\mathrm{NaCl} ; \mathrm{pH} 7.2 ; 2 \times 15 \mathrm{~min})$ and DNA was transferred overnight to a nylon membrane in $20 \times \operatorname{SSC}(3.0 \mathrm{M}$ $\mathrm{NaCl}, 0.3 \mathrm{~m}$ trisodium citrate, $\mathrm{pH} 7.5$ ). The DNA was fixed by baking the membrane for $2 \mathrm{~h}$ at $80^{\circ} \mathrm{C}$ (Southern, 1975).

Membranes were prehybridized in a rolling glass cylinder for $1 \mathrm{~h}$ in a solution of $750 \mathrm{~mm} \mathrm{NaCl}, 50 \mathrm{~mm}$ $\mathrm{NaH}_{2} \mathrm{PO}_{4}, 5 \mathrm{~mm} \mathrm{Na} \mathrm{N}_{2}$ EDTA, 0.1 per cent polyvinylpyrrolidone, 0.1 per cent bovine serum albumin, 0.1 per cent Ficoll, 0.1-5 per cent SDS, $10 \mu \mathrm{g} \mathrm{ml} \mathrm{m}^{-1}$ sheared denaturated $E$. coli DNA, and 1 per cent blocking reagent (Boehringer Mannheim) ( $\mathrm{pH}$ 7.4). For hybridization the dUTP-digoxigenin labelled (GATA) 4 (Fresenius) was added to the prehybridization solution to a final concentration of $5 \mathrm{~nm}$ and incubated for at least $3 \mathrm{~h}$ at $30^{\circ} \mathrm{C}$. The membranes were washed three times in $6 \times \mathrm{SSC}(0.9 \mathrm{M} \mathrm{NaCl}, 0.09 \mathrm{~m}$ trisodium citrate, $\mathrm{pH} 7.5$ ) for $30 \mathrm{~min}$ each to remove unspecifically hybridized oligonucleotides. After blocking for $1 \mathrm{~h}$ $(6 \times \mathrm{SSC}, 0.5$ per cent blocking reagent $)$ the membranes were equilibrated in antibody buffer $(0.9 \mathrm{M}$ $\mathrm{NaCl}, 0.1 \mathrm{~m}$ Tris, $\mathrm{pH} 7.5,20^{\circ} \mathrm{C}$ ) and incubated in antibody solution (anti-digoxigenin antibody linked with alkaline phosphatase (Boehringer Mannheim) diluted 1:10000 in antibody buffer). After 30 min free antibodies were removed by washing in antibody buffer three times for $15 \mathrm{~min}$ each. The membranes were briefly equilibrated in AP buffer $(0.1 \mathrm{M}$ Tris, $0.1 \mathrm{M}$ $\mathrm{NaCl}$, $\left.50 \mathrm{~mm} \mathrm{MgCl}_{2}\right)$, and incubated in detection buffer (1:100 dilution of Lumingen PPD ${ }^{\circledR}$, Boehringer Mannheim), and finally sealed in plastic wrap to be exposed to X-ray film. The banding pattern was analysed by computer using the $\mathrm{EASY}^{\circledR}$ package (UVP).

\section{Results}

Figure 1 shows a gel containing worker offspring of the $A$. $m$. capensis mother queen of the laying worker tested. Twelve fragments which are present in the laying worker proved to be polymorphic in the queen offspring. The laying worker offspring did not reveal any variation with an identical fragment pattern in all 34 individuals (Fig. 2). Another sample of 13 offspring workers of a laying worker from a different colony (data not shown) also revealed no variability. Given that we tested a total of 12 independent variable loci in 47 individuals, we considered up to 564 independent meiotic events in our data set. In this case crossing-over could have contributed to genetic variability only in less than 0.17 per cent of the tested variable loci.

\section{Discussion}

We could clearly support Tucker's model (Tucker, 1958) and Verma \& Ruttner's (1983) observations that there is a central fusion of the meiotic products in the thelytokous parthenogenesis of the Cape honeybee. The observed deficit of random recombination in automixis is possible only under the central fusion mechanism. However, the complete lack of any recombination is surprising, since gene exchange between homologous chromosomes is expected to occur through crossingover, unless the two tested laying workers were homozygous for all marker loci, which seems unlikely in the light of the 12 variable markers. 
Greeff \& Villet (1993) recently argued on a theoretical basis that crossing-over might contribute substantially to genetic variability in laying worker offspring of the Cape honeybee. They cited Verma \& Ruttner's (1983) cytological observations on the number of

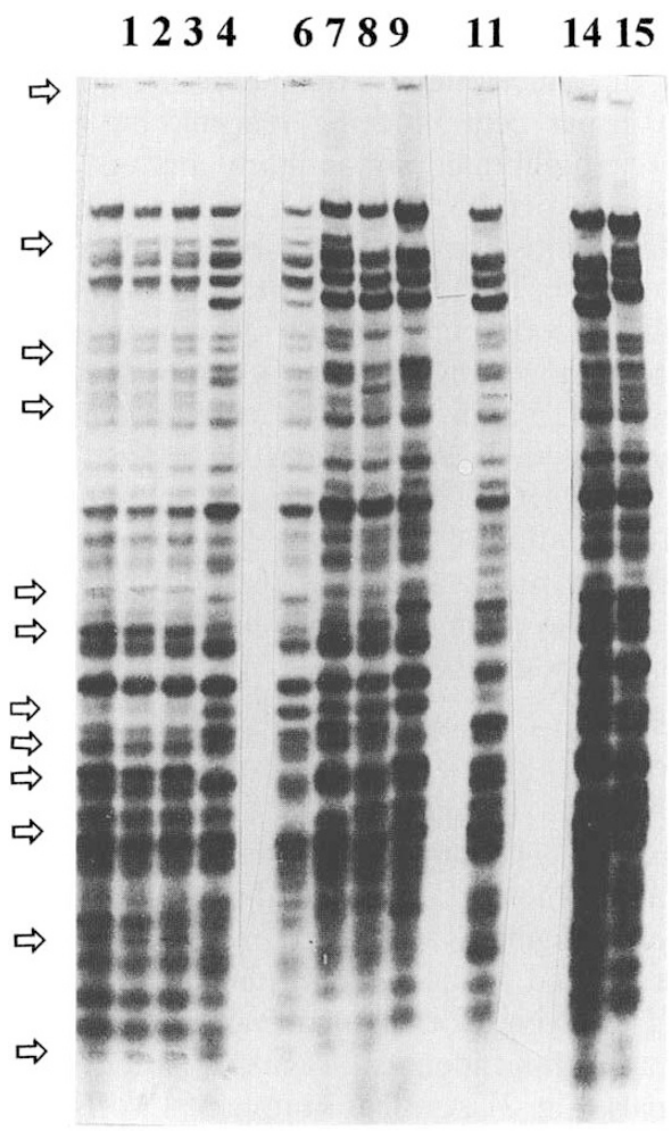

$12.6 \mathrm{~kb}$

$4.2 \mathrm{~kb}$

$3.1 \mathrm{~kb}$

$1.5 \mathrm{~kb}$

Fig. 1 Worker offspring of an Apis mellifera capensis queen (lanes 3-15). Also shown (lanes 1 and 2) are offspring of the worker in lane 3 . Twelve of the laying worker fragments are variable in the queen offspring sample (arrows). chiasmata as an estimator for the number of crossovers. However, crossing-over during the first meiotic division results in recombination only if there is noncomplementary gene exchange between the chromatids that will be peripheral and central after the second meiotic division, as in 'disparate' recombination where more than two chromosomes participate in crossingover (Sybenga, 1975). 'Compensating' chiasmata which result in gene exchange between the peripheral or central meiotic products during the first meiotic division as suggested by Fig. 2 (p. 500) in Greeff \& Villet (1993) can contribute to genotypic variability only if one assumes a random rearrangement of the chromosomes after the first meiotic division. Yet Sybenga (1975) argues that it is a general feature of meiosis that the first meiotic metaphase determines the orientation of the chromosomes and the genetic composition of the gametes. In many organisms the chromosomes pass directly to the equatorial plate of the second division (Cohn, 1969). Random rearrangement may be prohibited in the case of Apis mellifera capensis because of the strict linear order of the four meiotic nuclei after the second meiotic division (Verma \& Ruttner, 1983). This has significant impact on the model presented by Greeff \& Villet (1993) because of the strong bias in favour of compensating recombination in other organisms (Hearne \& Huskins, 1935; Huskins \& Newcombe, 1941).

Our empirical results clearly do not agree with Greeff \& Villet's theoretical expectations. In no case could we find an indication for genetic variability through crossing-over. There are several explanations for the lack of recombination other than the unlikely case of homozygosity at all 12 marker loci in the laying workers tested.

$12.6 \mathrm{~kb}$

$4.2 \mathrm{~kb}$

Fig. 2 Worker offspring of a laying capensis worker. All 34 offspring workers reveal the identical fragment pattern of the laying worker. 
Firstly, the markers we tested might not be distributed randomly in the genome. It is well known that repetitive sequences are particularly frequent near the centromere where crossing-over is rare. On the other hand, repetitive sequences are also abundant in telomeric positions which are believed to have a high probability of crossing-over. Therefore, this explanation would hold true only if (GATA) $)_{4}$ were a specific marker for the centromere. Yet there is no empirical evidence in support of such a hypothesis, and the $(\text { GATA })_{4}$ oligonucleotide repeat has been shown to be particularly predominant in telomeric positions of human chromosomes (Zischler et al., 1989).

Another explanation for the lack of genetic variability could be that crossing-over between a 'central' and 'peripheral' chromatid in the first meiotic division is a rare event in meiosis of laying worker honeybees. Unfortunately not much is known about crossover frequencies in honeybees, and this is in part due to the small number of linkage groups. Kauhausen (1978) used frequencies of mutant markers to study the mode of thelytokous parthenogenesis in hybrid workers of $A$. $m$. capensis and $A$. m. carnica. She found substantial numbers of homozygote offspring workers and estimated crossover frequencies of 36 per cent at the chartreuse locus ( $c h$, sample size: $n=50$ workers), 25.7 per cent at the cream locus $(c r, n=122), 3.9$ per cent at the bayer locus $(b a, n=1190), 8.2$ per cent for cordovan ( $c d, n=659)$, and 1.6 per cent for a whiteeyed mutant $(n=1012)$. These data contrast with our findings, since crossover frequencies exceeding 30 per cent would inevitably have shown up in our sample size. However, since racial hybrids were used, the parthenogenesis may not reflect the same mode of automixis as in $A . m$. capensis workers. This becomes particularly obvious since Kauhausen (1978) found a high frequency of male offspring in the progeny of laying hybrid workers, indicating that the fates of the meiotic nuclei are very different indeed compared to that of $A . m$. capensis workers which exclusively produce female offspring.

The presented molecular technique offers a direct tool to determine relationships among laying worker offspring instead of using the laborious and imprecise quantitative genetic approach suggested by Greeff \& Villet (1993). Our data indicate that genetic variation among $A$. $m$. capensis workers is extremely small, and in our sample the DNA fingerprint pattern in the worker offspring is similar to that of a genetic clone. A lack of recombination would have significant implications for natural selection in the Cape honeybee (Moritz, 1990) and the estimation of quantitative genetic parameters using laying workers (Moritz \& Klepsch, 1985). The difficulties expressed by Greeff \&
Villet (1993) concerning the genetic relationship estimates between offspring of laying $A . m$. capensis workers seem to be negligible.

\section{Acknowledgement}

We are grateful to N. Koeniger for providing us with the $A . m$. capensis queen. We thank D. Kauhausen for valuable discussions, and for sending us her unpublished data on the crossing-over frequencies in hybrid honeybees. The Deutsche Forschungsgemeinschaft granted financial support to conduct this study.

\section{References}

ANDERSON, R. H. 1968. The laying worker in the Cape honeybee, Apis mellifera capensis. J. Apic. Res., 2, 85-92.

BUTLER, C. G., CALLOW, R. K. AND JOHNSTON, N. C. 1961. The isolation and synthesis of queen substance, 9-oxodec-2-enoic acid, a honeybee pheromone. Proc. Roy. Soc. Lond., B155, 417-432.

CoHn, N. s. 1969. Elements of Cytology, 2nd edn. Harcourt, Brace and World, New York.

DUPRAW, E. J. 1967. The honeybee embryo. In: Wilt, F. H. and Wessels, N. K. (eds) Methods in Developmental Biology, pp. 183-217. Crowell, New York.

EPPLEN, J. T. 1988. On simple repeated GATA/GACA sequences: a critical reappraisal. J. Hered., 79, 409-417.

EPPLEN, J. T. AND ZISCHLER, H. 1989. DNA Fingerprinting with Oligonucleotides. Fresenius, Oberursel.

GREEFF, J. M. AND VILLET, M. H. 1993. Deducing the coefficient of relationship by the amount of recombination produced during automictic parthenogenesis. Heredity, 70, 499-502.

HABERL, M. AND MORITZ, R. F. A. 1994. Estimation of intracolonial worker relationship in a honeybee colony (Apis mellifera L.) using DNA fingerprinting. Insect. Soc. (in press).

HEARNE, E. M. AND HUSKINS, C. L. 1935. Chromosome pairing in Melanoplus femur-rubrum. Cytologia, 6, 123-147.

HUSKINS, C. L. AND NEWCOMBE, H. B. 1941. An analysis of chiasma pairs showing chromatid interference in Trillium erectum L. Genetics, 26, 101-127.

Kauhausen, D. 1978. Genetische Analyse der thelytoken Parthenogenese bei der Kap-Honigbiene (Apis mellifera capensis Esch.). Unpublished Thesis, J. W. Goethe Universität, Frankfurt/Main.

MORITZ, R. F. A. 1990. Natural and artificial selection in the Cape honeybee Apis mellifera capensis. In: Anderson, R. H. and Buys, B. (eds) Bees and Beekeeping in Southern Africa, pp. 63-73. POSA \& WPBA, Cape Town.

MORITZ, R. F. A. AND KLEPSCH, A. 1985. Estimating heritabilities of worker characters: a new approach using laying workers of the Cape honeybee (Apis mellifera capensis Esch.). Apidologie, 16, 47-56.

MORITZ, R. F. A., MEUSEL, M. AND HABERL, M. 1991. Oligonucleotide DNA fingerprinting discriminates super and halfsisters in honeybee colonies (Apis mellifera L.). Naturwissenschaften, 78, 422-424. 
ONIONS, G. W. 1912. South-African 'fertile worker bees'. Agric. J. Union S. Africa, 3, 720-728.

PAGE, R. E. AND ERICKSON, E. E. 1988. Reproduction by worker honey bees (Apis mellifera). Behav. Ecol. Sociobiol., 23, 117-126.

SAMBROOK, J., FRITSCH, E. F. AND MANIATIS, T. 1989. Molecular Cloning - a Laboratory Manual, 2nd edn. Cold Spring Harbor Laboratory Press, New York.

SNOdgrass, R. E. 1925. Anatomy and Physiology of the Honeybee. McGraw-Hill, New York.

SOUTHERN, E. 1975. Detection of specific sequences among DNA fragments separated by gel electrophoresis. J. Mol. Biol., 98, 503-517.

Sybenga, J. 1975. Meiotic Configurations. Springer Verlag, Berlin.
Sylvester, H. A. 1986. Biochemical genetics. In: Rinderer, T. E. (ed.) Bee Genetics and Breeding, pp. 177-203. Academic Press, Orlando.

TUCKER, K. W. 1958. Automictic parthenogenesis in the honeybee. Genetics, 43, 299-316.

TUCKER, K. W. 1986. Visible mutants. In: Rinderer, T. E. (ed.) Bee Genetics and Breeding, pp. 57-90. Academic Press, Orlando.

VERMA, S. AND RUTTNER, F, 1983. Cytological analysis of the thelytokous parthenogenesis in the Cape honeybee, (Apis mellifera capensis Escholtz). Apidologie, 14, 41-57.

ZISCHLER, H., NANDA, r., SCHÄFER, R., SCHMID, M. AND EPPLEN, J. T. 1989. Digoxigenated oligonucleotide probes specific for simple repeats in DNA fingerprinting and hybridization in situ. Hum. Genet., 82, 227-233. 